\title{
WHAT CANADIAN OIL AND GAS COMPANIES NEED TO KNOW ABOUT U.S. ANTITRUST LAWS
}

\author{
THERESA J. ARNOLD'
}

The author presents an introduction to and a cautionary warning about the idiosyncrasies, complexities and dangers of U.S. antitrust law for the Canadian oil and gas industry in a post-NAFTA economic and legal reality. Pre-NAFTA transborder Canadian rules, customs and business practices in the oil and gas industry may have to be reconsidered in light of the serious implications of U.S. antitrust jurisprudence to date. The reach and the scope of U.S. Title 15 Trade and Commerce legislation, such as the Sherman Act, the Clayton Act, the Robinson-Patman Act, the Federal Trade Commission Act, the Foreign Trade Antitrust Improvements Act, and the Hart-Scott-Rodino Act are outlined and presented. The author also describes the powers and authority of the United States Department of Justice, the United States Federal Trade Commission, the state attorneys general, and the "private" attorneys general to launch civil actions, class actions and criminal prosecutions serially, concurrently or in combination should an unwary foreign or domestic person run afoul of U.S. antitrust law. In addition, the author discusses the relevant leading case law, legal tests and legal principles, remedies, penalties, consequences and pitfalls of U.S. antitrust law.

\section{TABLE OF CONTENTS}

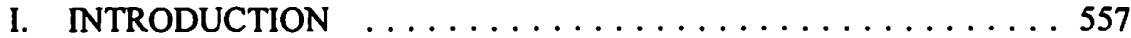

II. THE APPLICABLE LAW $\ldots \ldots \ldots \ldots \ldots \ldots \ldots \ldots \ldots \ldots$

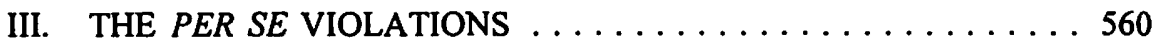

IV. CRIMINAL PROSECUTIONS $\ldots \ldots \ldots \ldots \ldots \ldots \ldots \ldots \ldots$

V. CIVIL LITIGATION $\ldots \ldots \ldots \ldots \ldots \ldots \ldots \ldots \ldots \ldots \ldots$

VI. PROVING ILLEGAL CONDUCT $\ldots \ldots \ldots \ldots \ldots \ldots \ldots \ldots 564$

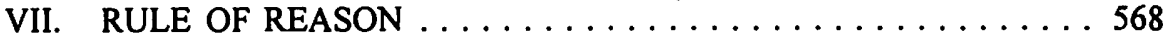

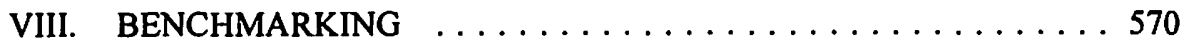

IX. APPLICATION TO FOREIGN CONDUCT $\ldots \ldots \ldots \ldots \ldots 571$

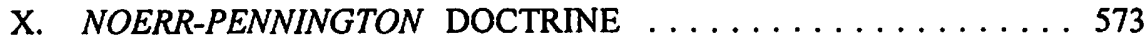

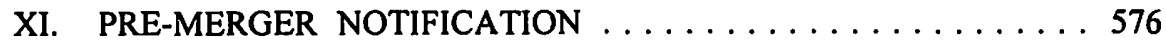

XII. CONCLUSION .................... 578

\section{INTRODUCTION}

Even before the passage of the North American Free Trade Agreement, 'the market in the United States beckoned Canadian oil and gas producers. Since the passage of NAFTA, the market is even more accessible to Canadian companies. Given the impact of NAFTA and the integration of North American natural gas markets, it is virtually impossible for a Canadian company to wall itself off from the impact of United States antitrust laws. Canadian companies exporting oil and gas to the United States need to know that United States antitrust laws apply to their export activities and they need to know the basics of those antitrust laws. 
Prosecutions under the antitrust laws of the United States operate on a premise of human economic behaviour described by Adam Smith in The Wealth of Nations: ${ }^{2}$ "People in the same trade seldom meet together, even for merriment and diversion, but the conversation ends in a conspiracy against the public, or in some contrivance to raise prices." There is also a strong current of economic belief underlying many court decisions since the mid-1970s that some describe as the Chicago school of economics. Simply, if somewhat inaccurately, stated, it is that for the most part markets left to themselves operate to reduce consumer prices and increase customer choice, and that this is a good thing. While not wholly inconsistent, juxtaposing the two beliefs about economic man occasionally results in inconsistent outcomes, leading to intense debate in the antitrust bar. While there are fierce debates going on, and in some ways a dual system of antitrust economic analysis - one in the courts and another in the enforcement agencies - when it comes to the fundamental issues, antitrust law has been reasonably consistent since the mid-1970s regardless of political change in the administrations.

\section{THE APPLICABLE LAW}

The basic antitrust laws are the Sherman $A c t,{ }^{3}$ s. 1 of which prohibits contracts, combinations or conspiracies in restraint of trade and s. 2 of which prohibits monopolization and conspiracies to monopolize; the Clayton Act, ${ }^{4}$ s. 3 of which prohibits anticompetitive tying arrangements and exclusive dealing and s. 7 of which prohibits acquisitions or mergers that may lessen competition or create monopoly; and the Robinson-Patman Act, ${ }^{5}$ which prohibits charging different buyers different prices for goods of like grade and quality.

The Federal Trade Commission $A c t^{6}$ established an administrative agency with authority to investigate violations of the antitrust laws. The Federal Trade Commission ("FTC") also has concurrent jurisdiction with the United States Department of Justice ("DOJ") to review proposed acquisitions or mergers. Section 5 of the FTCA prohibits unfair methods of competition. The FTC takes the position that this permits it to prohibit conduct that is not necessarily otherwise prohibited by the antitrust laws, but

A. Smith, An Inquiry Into the Nature and Causes of the Wealth of Nations (Chicago: The University of Chicago Press, 1976).

Section 1: "Every contract, combination in the form of trust or otherwise, or conspiracy, in restraint of trade or commerce among the several States, or with foreign nations, is declared to be illegal...."

Section 2: "Every person who shall monopolize, or attempt to monopolize, or combine or conspire with any other person or persons, to monopolize any part of the trade or commerce among the several States, or with foreign nations, shall be deemed guilty of a felony..."

15 U.S.C. $\$ 12$ (1988).

15 U.S.C. $\$ 13$ (1988). The Robinson-Patman Act is highly technical and a lawyer familiar with it can normally work within it. This article does not discuss the Robinson-Patman Act, except to note that the $A c t$ does not permit different prices for different quantities. On the contrary, the $A c t$ was first passed partly in response to the perceived unfaimess of big supermarket chains getting an unfair advantage over the comer grocer because they could qualify for quantity discounts.

$6 \quad 15$ U.S.C $\$ 45$ (1984) [hereinafter FTCA]. 
which "contravene[s] the public policies behind them...."7 The FTC has asserted that a "showing of actual anticompetitive effect is unnecessary [because s. 5] was designed to stop in their incipiency acts and practices that could lead to violations of the Sherman or Clayton Acts. ${ }^{8}$ The courts to whom decisions and remedies based solely on $\mathrm{s} .5$ have been appealed have disagreed with this assertion. ${ }^{9}$ This issue has not been conclusively resolved by the United States Supreme Court.

In addition to the federal antitrust laws, most states have passed antitrust and unfair trade laws. Sometimes lawyers not satisfied with the trend in antitrust decisions in federal courts will file an antitrust action in state courts under state antitrust or unfair trade laws seeking a different outcome. However, for the most part, these state laws parallel the federal antitrust laws and the state courts tend to follow federal court precedents in applying the state laws.

The entities with authority to enforce the antitrust laws are varied and numerous. They include the DOJ and the FTC, of course, and also the attorneys general of the various states under both state unfair trade laws and federal antitrust statutes. Unique to the system in the United States is the concept of "private attorneys general." The impact of the "private attorney general" on the antitrust landscape will be discussed below.

The elements of a Sherman Act s. $1^{10}$ violation are:

(1) an agreement;

(2) between two or more entities;

(3) that unreasonably restrains trade;

(4) in interstate or foreign commerce.

The existence of an agreement between two or more legal entities can be inferred from circumstantial evidence. "Section 1 of the Sherman Act does not reach unilateral conduct of a single entity, but requires evidence that two or more entities are involved. $^{12}$

A useful distinction to remember is that between "horizontal" and "vertical" agreements. Horizontal agreements are those among companies that are direct competitors at the same level of distribution. Agreements between direct competitors about any matter of commercial significance, such as the prices they will charge, are assumed to unreasonably restrain trade - they are considered illegal per se. Agreements between a company and its distributors and retailers at different levels of

7 The Coca Cola Co., 5 Trade Reg. Rep. (CCH) q 23,625 at 23,326 (final opinion and order issued 13 June 1994) [hereinafter Coca Cola].

$8 \quad$ Ibid. at 23,326 .

$9 \quad$ See e.g. E.I. du Pont de Nemours \& Co. v. FTC, 729 F.2d 128 (2nd Cir. 1984).

10 Supra note 3.

1 Interstate Circuit, Inc. v. United States, 306 U.S. 208 (1939); Eastern States Retail Lumber Dealers' Ass'n v. United States, 234 U.S. 600 (1914).

12 Copperweld Corp. v. Independence Tube Corp., 467 U.S. 752 at 767-68 (1984). 
distribution are considered "vertical" agreements. Whether such agreements unreasonably restrain trade is analyzed under the "rule of reason." ${ }^{13}$

\section{THE PER SE VIOLATIONS}

Per se violations are conduct the courts have concluded unreasonably restrain trade no matter what the excuse. The U.S. Supreme Court concluded many years ago that some conduct is so pernicious and so devoid of pro-competitive justification that it is unreasonable without proof of its effects: "[R]easonability is of no consequence when certain practices, for example, price fixing, are entirely void of redeeming competitive rationales. These we deem per se illegal under section 1, no offsetting economic or efficiency justifications salvaging them. ${ }^{114}$ It is illegal per se. This characterization of the offence dictates the applicable method of antitrust analysis. There are no defences based on the effects of the conduct. If you did it, you are guilty. The agreement is the violation, even if it is never implemented and even if it is a complete failure. ${ }^{15}$

The list of anticompetitive conduct which courts have concluded fall in the per se category may be stated as follows.

Competitors may not agree:

(1) on prices they charge for goods;

(2) on prices they charge for services;

(3) on terms of sale;

(4) on levels of production;

(5) to allocate customers, territories or markets;

(6) not to compete on bids - bid rigging;

(7) on prices for products or services they buy; or

(8) to join a boycott of suppliers or customers to accomplish anti-competitive ends.

The distinction between horizontal and vertical agreements gets complicated when a company both distributes its product through independent distributors and sells it directly. This circumstance is called "dual distribution." In such situations, the relationship between the companies is simultaneously vertical (supplier/distributor) and horizontal (competitors). Since the outcome will vary depending on whether the agreement is characterized as "horizontal" or "vertical," a lot of the decisions written during the 1970s and 1980s contained long confusing discussions of whether the commercial relationship between the parties to an agreement was either "vertical" or "horizontal." Most recent cases tend to treat such restraints as vertical and apply a rule of reason analysis: Illinois Corporate Travel, Inc. v. American Airlines, Inc., 889 F.2d 751 at 753 (7th Cir. 1989), cert. denied, 495 U.S. 919 (1990); Dart Industries, Inc. v. Plunkett Co. of Oklahoma, Inc., 704 F.2d 496 at $498-99$ (10th Cir. 1983) (manufacturer's "dual distribution" system lawful); $H \& B$ Equipment Co. v. International Harvester Co., 577 F.2d 239 at 245-46 (5th Cir. 1978) (conspiracies between a manufacturer and its dealers treated as horizontal only when the source of the conspiracy is a combination of dealers). 
Furthermore, a seller may not tell its customers how much to charge for the product. Resale price maintenance is illegal per $s .^{16}$

\section{CRIMINAL PROSECUTIONS}

Criminal prosecutions are invariably against per se violations. The catalogue of per $s e$ offences puts people on notice of what kind of agreement may be prosecuted as felonious. The perceived unfairness in many cases arises from the nature of the evidence used to prove the unlawful agreement.

For individuals, the criminal penalties are fines up to U.S. $\$ 350,000$ and up to three years in jail. Under the United States Sentencing Guidelines, ${ }^{17}$ individuals will serve time. The days of community service probation have long passed. For companies, the criminal penalties are fines up to U.S. $\$ 10$ million per violation. Under the United States Sentencing Guidelines for organizations, companies are subject to millions of dollars in fines ranging from 15 percent to 80 percent of the amount of commerce affected by the violation. ${ }^{18}$

The DOJ aggressively prosecutes agreements between or among competitors about the prices they will charge for their products. It seeks jail time for every individual involved in any price-fixing agreement. It has stated its intention to treat price-fixing offences like any street crime.

The present United States Assistant Attorney General for Antitrust is Anne Bingaman. One of her themes is the globalization of antitrust. Ms. Bingaman has stated her commitment to vigourous enforcement of antitrust laws, particularly against foreign companies fixing prices affecting United States commerce. She is also committed to international cooperation in antitrust enforcement. ${ }^{19}$

The Director of Investigation and Research of the Canadian Bureau of Competition Policy agrees with Ms. Bingaman:

In the new global economy, antitrust agencies and competition authorities are going to be pursuing more and more cases where cooperation and coordination will be necessary to ensure healthy and competitive markets.... International cooperation is here to stay, it is going to intensify, and it is going to yield results. ${ }^{20}$

Resale price maintenance has been illegal per se since 1911: Dr. Miles Medical Co. v. John D. Park \& Sons Co., 220 U.S. 373 (1911); 31 S. Ct. 376 (1911); 55 L.Ed. 502 (1911). Nonprice restrictions on customers (e.g. exclusive territories) have been govemed by the rule of reason since the Supreme Court decision in Continental T.V., Inc. v. GTE Sylvania Inc., 433 U.S. 36 (1977). 18 U.S.C.A. \$ 1 B1.1ff (West, 1995).

Ibid.

See Ms. Bingaman's speech before the American Bar Association, Antitrust Section (April 1995) 1995, WL 217866 (DOJ).

Remarks of G. Addy, Director of Investigation and Research, Bureau of Competition Policy, to the Canadian Manufacturers' Association (Ottawa: Govemment of Canada, March 1995). 
As part of the Mutual Legal Assistance Treaty ${ }^{21}$ between Canada and the United States for criminal matters, there is a Memorandum of Understanding ${ }^{22}$ regarding antitrust enforcement. This is the only one of many mutual assistance agreements to which the United States is a party which has been used in antitrust criminal enforcement. In June 1994, the DOJ obtained criminal plea agreements from three manufacturers of plastic dinnerware and four of those manufacturers' executives. They had allegedly conspired to fix prices of plastic dinnerware sold to large purchasers. The RCMP had cooperated and assisted in the investigation by seizing documents in Canada. Criminal fines have exceeded U.S. $\$ 8$ million. ${ }^{23}$ The president of one of the manufacturers entered a guilty plea and was recently sentenced to twenty-one months in prison and a U.S. $\$ 90,000$ fine. ${ }^{24}$

In the summer of 1994, U.S. and Canadian authorities cooperated in prosecuting a Japanese company, two U.S. subsidiaries of Japanese companies and the former president of one of the U.S. companies for conspiring to fix the price of fax paper in North America. ${ }^{25}$ As a result, the two nations' antitrust authorities obtained guilty pleas and agreements to pay criminal fines of over U.S. \$6 million and Cdn. \$1 million.

A company can find itself defending against charges that it unlawfully agreed with a competitor to fix the price of the products they sell even though, from the company's perspective, it was engaged in perfectly lawful and legitimate commercial conduct. Furthermore, the facts supporting the prosecution of the company can arise from the conduct of its customers.

The DOJ or the FTC may also bring actions for civil remedies and penalties and may seek injunctive relief prohibiting the unlawful conduct. ${ }^{26}$ It is not uncommon for consent decrees negotiated with the DOJ or the FTC to include provisions that prohibit otherwise lawful conduct to "fence in" the company from conduct that may result in a violation of the antitrust laws. Such provisions are "designed to stop in their incipiency, acts and practices that could lead to violations of the Sherman or Clayton Acts."27

See Mutual Legal Assistance in Criminal Matters Act, R.S.C. 1985 (4th Supp.) c. 30 and R.S.C. 1985 (4th Supp.) c. 30, Sch.; SOR/90-704.

22 Ibid. Memorandum of Understanding between United States and Canada, August 1995.

23 See DOJ, Press Release, "Plastic Dinnerware Price Fixing Probe Nets Indictment, Guilty Plea Agreements" (9 June 1994); reprinted in (16 June 1994) 66 Antitrust \& Trade Reg. Rep. (BNA) 661 .

$24 \quad$ "Top Corporate Official Suffers Big Penalty on Price Fixing Conviction" (23 March 1995) 68 Antitrust \& Trade Reg. Rep. (BNA) 399.

25 United States v. Kanzai Specialty Papers, Inc., 6 Trade Reg. Rep. (CCH) I 45,094 No. 4086 (D. Mass. 1994).

26. In United States v. Pilkington plc, 7 Trade Reg. Rep. (CCH) I 70,842 (D. Ariz. 1994), the DOJ entered into a consent order with Pilkington plc, the world's largest producer of flat glass. The DOJ claimed that Pilkington used restrictive licensing practices to impose territorial allocations on the manufacturers of flat glass after its patents had expired. The DOJ argued that these license restrictions prevented U.S. firms from designing, building or operating flat glass plants overseas. 


\section{CIVIL LITIGATION}

The most likely way a company will be introduced to U.S. antitrust law is through a civil action filed by a competitor, a customer or a state attorney general. Anyone who is injured by an antitrust violation may sue the companies involved for three times the amount of the damage and attorney's fees. Several individuals injured by the antitrust violation may join together in a class action, thus justifying pursuit of claims that would not warrant the expense of litigation if pursued separately. This is precisely what the municipal natural gas customer that filed an action against Pacific Gas \& Electric ("PG\&E") attempted to do. The plaintiff customer alleged that PG\&E conspired with Canadian gas producers to fix prices for Canadian gas PG\&E bought and then resold to California customers. The plaintiff sought to have the case certified as a class action on behalf of all California municipalities and consumers. ${ }^{28}$ In an opinion issued on August 25, 1994, the district judge granted class certification, but dismissed most of the antitrust claims under the "filed rate doctrine." ${ }^{129}$ The "filed rate doctrine" prevents parties from recovering antitrust damages for paying rates that were approved by a regulatory authority. ${ }^{30}$ Although not named as defendants in the case, Canadian oil companies that entered into supply agreements with Alberta \& Southern Gas (a subsidiary of PG\&E) were listed in Exhibit $A$ to the complaint as participants in the conspiracy. ${ }^{31}$

It is not uncommon for civil litigation by injured parties to follow on the heels of an antitrust prosecution. The availability of class actions and triple damage remedies improves the economics of the litigation for the plaintiffs and increases the number of cases filed and the size of the settlements. State attorneys general may also sue on behalf of the citizens of their states, and often do so, if they believe the DOJ has not been sufficiently aggressive. The Petroleum Products ${ }^{32}$ litigation discussed below was such a lawsuit brought by the attorneys general of several states. All of the defendants eventually settled in that case.

Defendants settle these cases because litigation costs are astronomical. For example, in the prosecution of GE for allegedly agreeing with DeBeers to fix the prices of industrial diamonds, GE reportedly spent over U.S. $\$ 20$ million during the approximately one-year period the case was pending. ${ }^{33}$ As high as that dollar figure is, it pales beside the expense of defending a massive civil antitrust case against an entire industry that can drag on for years with full scale document discovery.

County of Stanislaus v. Pacific Gas \& Electric Co., No. CV-F-93-5688 (E.D. Cal.). County of Stanislaus v. Pacific Gas \& Electric Co., 1994 WL 706711 (E.D. Cal.).

The filed rate doctrine is much more complicated to litigate than it is to state. The opinion contains a lengthy discussion of the history of the filed rate doctrine and of the various ways in which natural gas prices and transportation are regulated by the United States federal and state governments, in this case, the California Public Utility Commission.

Supra note 28.

Infra note 36.

W.W. Horne, "GE Crushes the Trustbusters" The American Lawyer (Jan./Feb. 1995) 61. 


\section{PROVING ILLEGAL CONDUCT}

Many hardcore price-fixing conspiracies are relatively easy to prove by direct evidence. The government has the conspirators on tape, or has notes of meetings outlining the agreement, or has a participant turned state's evidence to testify to the illegal agreement. That is relatively straightforward and the government uses the usual tools prosecutors have at their disposal to collect direct evidence to prove their cases. Prosecutors routinely use circumstantial evidence to prove crimes.

The extent to which exchanges of price information may be used as circumstantial evidence of an agreement to fix prices is an ongoing source of concern in advising clients. Exchanges of price information are not themselves per se illegal but price information exchanges are often used as evidence of conspiracy. ${ }^{34}$ While courts claim to be alert to the potential chilling effect on neutral or pro-competitive conduct of rules making all communications the basis for a potential civil or criminal case, one cannot predict when advising clients how particular communications will look in the context of a criminal or a civil antitrust case.

"Conscious parallelism" is another approach to establishing that the market participants entered into illegal agreements. It is seen in markets in which market participants base their own pricing decisions on what their competitors are doing. Two competitors charging the same price is not sufficient by itself to prove an agreement to fix prices. ${ }^{35}$ The courts require evidence of "plus" factors to permit a jury to conclude the parties have so agreed. If the prices are parallel, it does not take much to allege "plus" factors. Potential "plus" factors include:

(1) an exchange of information between competitors; or

(2) meetings among competitors; and

(3) no independent business reason for conduct which is against pecuniary interest.

This evidence is cumulative. If you add those activities to a pricing pattern that looks like conscious parallelism, then the opportunity for a jury to decide that the companies are guilty of a per se violation increases.

Re Coordinated Pretrial Proceedings in Petroleum Products Antitrust Litigation ${ }^{36}$ was a civil case brought by the attorneys general of several states against the major marketers of gasoline. The Court of Appeals for the Ninth Circuit reversed the District Court's grant of summary judgment to the defendants. The Ninth Circuit opinion is extremely complex but it is based in part on parallel prices plus public announcements of wholesale prices and various contacts among competitors.

Of particular interest here is the Court's treatment of the companies' practice of providing wholesale price information to the trade press on or shortly before its 
effective date. The Court rejected the justification that the practice was necessary to inform the companies' customers of price changes. The defendants' customers were branded marketers with whom the defendants could communicate directly about prices. A reasonable jury could conclude that the only purpose of the price announcements through the trade press was so that the defendants could communicate among themselves. Add communication through the trade press to the parallel pricing evidence and the jury could conclude that the defendants had an agreement to raise or stabilize prices.

The conclusion that one reaches after reading the Petroleum Products decision is that price announcements are defensible if made directly to the customers and if the announcements communicate only what the customer needs to know for legitimate business purposes - anything else is suspect. Even price announcements limited to customers should not be made too far in advance. Companies should avoid press releases and interviews about price moves. In particular, they should avoid discussing price moves with their competitors.

At bottom, the opinion in Petroleum Products reflects a certain distrust of the notion that price transparency is good for markets; at least in markets where the parties might engage in consciously interdependent behaviour. This is particularly worrisome in the natural gas market because various commercial index publishers seek information about current pricing for future delivery from companies (both buyers and sellers), publish an index and then the companies use the published indexes in negotiating price terms for long-term contracts. Even if a company declines to participate in providing pricing information to the index publisher, it has the commercial concern of whether the indexes on which prices in long-term supply contracts are calculated will survive as useful contractual reference points in the event of an antitrust attack on the indexes. In the wholesale gasoline market, many companies stopped providing their pricing information to the price information services following the decision in the Petroleum Products case. The same companies that refuse to provide pricing information still use the information available from the price information services in making their pricing decisions, but the quality of the information has deteriorated substantially.

The Petroleum Products litigation also included a claim that the oil companies had conspired not to expand refinery capacity in order to create a shortage. Economic theory teaches that one cannot have a successful price-fixing agreement if one cannot also control output. In the natural gas and oil businesses, companies should avoid discussing or commenting on levels of output in any forum. This is of particular concern in the natural gas business when prices are low and companies start to announce they are shutting in production. If this is accompanied by public pronouncements that everyone else should shut in production as well, then you have a classic example of communications guaranteed to catch the attention of government enforcement officials and the private plaintiffs' bar. It will come back to haunt the industry if there is a cold winter in New England, and a market which is highly dependent on gas imports from Canada as well as the United States Gulf Coast. 
Beware of exchanges of cost data. The U.S. courts will treat buyer agreements on the price they will pay just like seller price fixing. In fact, many of the cases cited in antitrust articles are actually buyers' cases when one looks at the facts. ${ }^{37}$ City of Long Beach v. Standard Oil Company of California ${ }^{38}$ was but one decision in the long saga of Re Coordinated Pretrial Proceedings in Petroleum Products Antitrust Litigation. ${ }^{39}$ The City of Long Beach, California owned the offshore Wilmington Oil Field. It had sold interests in production to a consortium of California oil companies to develop the field. The oil companies agreed to pay the city for the crude oil produced based on an average of prices posted by major purchasers in the Wilmington and other named fields. In 1975, the city sued seven major oil companies claiming that they had conspired "to fix and maintain uniform noncompetitive posted prices for the kind of crude oil produced from the Wilmington field." ${ }^{40}$ The city argued the oil companies were able to do this by bartering the crude oil through exchange agreements to maintain the value among themselves.

As is often the case in such litigation, once the Court of Appeals for the Ninth Circuit reversed the grant of summary judgment for the defendants and concluded the claims against the companies would go to a jury for resolution, the remaining defendants settled. Chevron, Texaco, Shell and Mobil paid U.S. $\$ 45$ million (plus dedication of certain pipelines to common carrier status) in 1991. ARCO had agreed to pay U.S. \$22.5 million to settle in 1984. UNOCAL settled for U.S. $\$ 77$ million in February 1991. Exxon held out and did not settle, probably because it never went to the meetings about the exchange agreement that were alleged to be the heart of the conspiracy. ${ }^{41}$ Exxon went to trial as the only remaining defendant in the case. The jury brought in a verdict in Exxon's favour, which the Court of Appeals for the Ninth Circuit upheld. ${ }^{42}$

Competitors should be wary of any kind of information exchange, as any such exchange can lead to allegations of an agreement. This is true even of one-sided communications. The DOJ has challenged certain communications as "invitations to collude," "price signaling" or attempts to monopolize. ${ }^{43}$

The scope of the agencies' concern with information exchanges is illustrated by the Statements of Enforcement Policy and Analytical Principles Relating to Health Care and Antitrust ${ }^{4}$ jointly issued by the DOJ and the FTC. The Statements set out

See e.g. Petruzzi's IGA Supermarkets, Inc. v. Darling-Delaware Co., Inc., 998 F. 2d 1224 at 1242 (3rd Cir. 1993).

872 F. 2d 1401 (9th Cir. 1989).

Supra note 36.

City of Long Beach, supra note 38 at 1403.

"Oil Companies Tentatively Resolve State's Accusations of Price Fixing" (29 August 1991) 61 Antitrust \& Trade Reg. Rep. (BNA) 278.

City of Long Beach v. Standard Oil Company of California, 46 F.3d 929 (9th Cir. 1995).

See Quality Trailer Products Corp., No. C-3403 (FTC, 1992); 1992 TRADE FTC LEXIS 270 (Invitation to Collude); United States v. Airline Tariff Publishing Co., 836 F. Supp. 9 (D.D.C. 1993) (Consent Decree to resolve allegations of price signaling).

Trade Reg. Rep. (CCH) I 13,152 (30 September 1994) [hereinafter Statements]. 
"antitrust safety zones" for the exchange of certain price and salary information. The very fact that the agencies believe companies need "antitrust safety zones" for the exchange of certain categories of information reveals the breadth of the agencies' belief that they can prosecute companies for exchanging that information if they stray too far from the "safety zones." Although expressly applicable only to the health care industry, the Statements are useful guidelines for any cost survey. The rules are not particularly novel. Competitor surveys: (1) should be managed by a third party; (2) should be based on data at least three months old; and (3) must include information from at least five participants for each statistic, with no individual participant's data representing more than 25 percent on a weighted basis of the statistic. The data must be aggregated so that no particular participant can be identified to its data. The explanation for the rules is enlightening: "The [rules] ... are intended to ensure that an exchange of price or cost data is not used by [competitors] ... for discussion or coordination of ... prices or costs." ${ }^{45}$

Trade associations are frequently the context for competitor contacts. Trade associations by definition are combinations of competitors, and their activities may be subject to scrutiny under s. 1 of the Sherman Act. $^{46}$ However, membership in a trade association is not sufficient evidence of an agreement to restrain trade. ${ }^{47}$ Many trade association activities, if conducted pursuant to appropriate antitrust guidelines, are recognized as "efficient, procompetitive, and useful, not only to the associations, but to customers and to government." 48 This includes statistical reporting activities, product standardization and standard setting, although any one of those activities could also result in antitrust liability if improperly conducted. In the United States, trade association activity to influence the government policy or legislative process is immune from antitrust prosecution under the Noerr-Pennington doctrine, which is discussed below. ${ }^{49}$ In sum, trade association activities must be conducted with firm adherence to antitrust guidelines, which may include having a lawyer at all trade association meetings. It certainly includes making sure that the association has and follows written antitrust guidelines.

Sometimes clients will form an informal association to deal with a narrow legislative, regulatory or standard-setting issue. Informal associations that have been formed among competing companies to work on issues do not have the same protection as regular trade association activity, mainly because they do not have the same kinds of procedural mechanisms in place to prevent the appearance of conspiratorial activity. The same is true of informal "rump" sessions within a trade association. In fact, both activities may more closely resemble garden variety conspiracies and should be

Ibid. at 20,784 .

Supra note 3; see Eastern States Retail Lumber Ass'n v. United States, 234 U.S. 600 (1914); Allied Tube \& Conduit Corp. v. Indian Head, Inc., 486 U.S. 492 (1988).

Greater Rockford Energy \& Technology Corp. v. Shell Oil Co., 998 F.2d 391 (7th Cir. 1993) (No evidence of concerted action).

Speech of Mary Lou Steptoe before the American Society of Association Executives (28 October 1993) 65 Antitrust \& Trade Reg. Rep. (BNA) 551.

See text accompanying infra notes 69 and 70 . 
avoided. It doesn't take much effort to set up a proper trade association structure if the activity should be pursued.

\section{RULE OF REASON}

In contrast to the per se rules, all other conduct is governed by the rule of reason. This approach weighs the anticompetitive effects of the conduct against its legitimate business justification. The inquiry is limited to the impact of the conduct on the market: does it increase output and/or does it decrease output and increase prices? For the most part, factors unrelated to the effect of the restraint on competition are irrelevant. Hence, an agreement among lawyers assigned to represent indigent criminal defendants to withhold services until the local authorities increased their pay was held illegal per se: a constitutional duty to represent indigent criminal defendants and a desire to provide quality representation did not justify a boycott for higher pay. ${ }^{50}$

A particularly lucid explanation of the rule of reason and its relationship to the per se rule can be found in SCFC ILC.

Section I [of the Sherman Act] forbids agreements in restraint of trade. Read costively, section 1 might prohibit "every conceivable contract or combination ... anywhere in the whole field of human activity." Standard Oil Co. of N.J. v. United States, 221 U.S. 1, 60, 31 S.Ct. 502, 516, 55 L.Ed. 619 (1911). However, "the 'rule of reason' limits the Act's literal words by forbidding only those arrangements the anticompetitive consequences of which outweigh their legitimate business justifications." Clamp-All Corp. v. Cast Iron Soil Pipe Inst., 851 F.2d 478, 486 (1st Cir.1988) (citing 7 P. Areeda \& D. Tumer Antitrust Law I 1500, at 362-63 (1978)), cert. denied, 488 U.S. 1007 (1989). Hence, when we ask if a particular practice is "reasonable" or "unreasonable," or if the practice is "anticompetitive," we use these terms with special antitrust meaning reflecting the "Act's basic objectives, the protection of a competitive process that brings to consumers the benefits of lower prices, better products, and more efficient production methods." Id. at 486. In this lexicon, a practice ultimately judged anticompetitive is one which harms competition, not a particular competitor. Brunswick Corp. v. Pueblo Bowl-O-Mat, Inc. 429 U.S. 477, 488, 97 S.Ct. 690, 697, 50 L.Ed.2d 701...(1977)...

Of course, reasonability is of no consequence when certain practices, for example, price fixing, are entirely void of redeeming competitive rationales. These we deem per se illegal under section 1, [of the Sherman $A c t$ ], no offsetting economic or efficiency justifications salvaging them. "This per se approach permits categorical judgments with respect to certain business practices that have proved to be predominantly anticompetitive." Northwest Wholesale Stationers, Inc. v. Pacific Stationery \& Printing Co., 472 U.S. 284, 289, 105 S.Ct. 2613, 2617, 86 L.Ed.2d 202 (1985).'s'

Since almost all horizontal restraints are considered illegal per se, most rule of reason cases arise out of vertical agreements between a seller and its customers. While resale price fixing is illegal per se, the courts have developed a large body of case law about nonprice vertical restrictions on product distribution. Examples of nonprice vertical restrictions are exclusive territories, requirements that the distributor operate 
from a specific location, and prohibitions on the distributor dealing in competitors' goods. Most courts currently use an approach to analyzing nonprice vertical restraints called the Chicago school of economics. Oversimplified, this approach sees the goal of antitrust law as the protection of competition - the process of commercial rivalry that is believed to create the most efficient economic outcome. Many of the nonprice restrictions that sellers place on their distributors are designed to improve the sellers' competitive position among its rivals ("interbrand competition"). Unless the seller has market power, the impact of the restriction on intrabrand competition (i.e. rivalry among the sellers' distributors) is not of antitrust significance.

"Market power" is the power "to force a purchaser to do something that he would not do in a competitive market." ${ }^{\text {"52 }}$ The usual proxy for "market power" is market share. This normally requires definition of the relevant product and geographic market. It is not uncommon for the definition of the relevant market to be outcome determinative in rule of reason cases. Many courts have adopted market power as a screening device to avoid having to do a full-scale rule of reason analysis of particular practices.

The current approach to the rule of reason analysis can be traced to Continental T.V., Inc. v. GTE Sylvania Inc. ${ }^{53}$ This was the government's approach to antitrust analysis during the 1980s. There is renewed debate in the legal literature about how well the Chicago school of economics describes competitive reality rather than a purely theoretical approach to markets. It is currently being challenged on a number of fronts, including government pronouncements in conjunction with its merger and acquisition reviews and the joint DOJ and FTC Antitrust Guidelines for the Licensing of Intellectual Property. ${ }^{54}$ The impact of this turmoil is that certainty has evaporated. Not all vertical acquisitions go unchallenged. The agencies threaten more attacks on nonprice restrictions on distributors in unconcentrated markets.

Legitimate joint ventures exist some place between mergers and cartels, and differ from both of them. The Supreme Court has rejected automatic per se treatment of joint ventures. In doing so, "the Court directs us instead to look at the challenged agreement to judge whether it represents the essential reason for the competitors' cooperation or reflects a matter merely ancillary to the venture's operation; whether it has the effect of decreasing output; and whether it affects price." 55 In some situations, the horizontal restraint may be essential to create the product in the first place, as was the case in

Kodak v. Image Technical Services, 504 U.S. 451 at 456-58 (1992) [hereinafter Kodak], citing and quoting Jefferson Parish Hospital District No. 2 v. Hyde, 466 U.S. 2, 17, (1984). Although these are both tying cases, for which the rule remains per se illegality, they both contained extensive discussions of market power as an element of a tying claim. 433 U.S. 36 (1977).

54 (13 April 1995) 68 Antitrust Trade Reg. Rep. (BNA) Special Supplement. The Winter 1995 issue of the ABA Antitrust Law Journal is devoted to the proposition that the Supreme Court's decision in Kodak, supra note 52, signals the demise of the Chicago school of economics. The courts do not necessarily accept this view of the Kodak decision. One may be forgiven for concluding on reading the articles that they are guaranteed to provide full employment for economists as well as lawyers, because one theme is the elimination of shortcuts (such as market power screens) to a full jury trial in every case.

ss $\quad$ SCFC ILC supra note 14 at 964 
Broadcast Music, Inc. v. Columbia Broadcasting, Inc. ${ }^{56}$ in which the Supreme Court approved blanket licences that amounted to price fixing among music copyright owners through a clearinghouse that monitored the use of their work. In another case, the Supreme Court implicitly accepted the function and operation of a purchasing cooperative which lacked market power. ${ }^{57}$

A joint venture is often an attractive way to enter unfamiliar markets. The first hurdle in looking at a joint venture is to distinguish it from a naked horizontal agreement in restraint of trade. Parties contemplating a joint venture in the United States or with U.S. companies need to make sure that the joint venture is creating something of real value that did not exist before. Simply entering an agreement to jointly control certain facilities and to exclude competitors will not pass muster. ${ }^{58}$ Even if the joint venture itself survives scrutiny, the impact of the joint venture agreement on other activities of the parties to it must be carefully designed to avoid anti-competitive impact. For example, while joint operating agreements are the typical way in which oil and gas properties are developed in the United States, the parties generally are careful to exclude marketing the output from the property from the scope of the agreement.

\section{BENCHMARKING}

Many times clients will attempt to justify exchanging information with their competitors by calling it "benchmarking." Because benchmarking activity is essentially an exchange of information, and because oil companies only want to do it with other oil companies, their competitors, it can be a particularly troubling activity. This is particularly the case when the activity called "benchmarking" devolves into simply doing extensive surveys on an unblinded basis of competitors' costs, which seems to be a trend in the Canadian oil and gas industry. It is too easy to create the inference that the exchange of cost (or worse yet, price) data may be used for the coordination of costs (or prices). If companies are just going to survey their competitors, then they ought to follow the kind of guidelines contained in the Statements. ${ }^{59}$

Properly conducted, benchmarking is an activity focused on the process by which companies get things done, like processing paperwork. Effective benchmarking is generally done outside a company's industry to find a better way of doing things that will make the company more cost effective and more competitive. Any activity

441 U.S. 1 (1979), 99 S.Ct. 1551 (1979); 60 L.Ed.2d 1 (1979).

Northwest Wholesale Stationers, Inc. v. Pacific Stationery \& Printing Co., 472 U.S. 284 at 289 (1985); 105A S.Ct. 2613 at 2617 (1985); 86 L.Ed.2d 202 (1985).

United States v. Terminal Railroad Association of St. Louis, 224 U.S. 383 (1912) (Railroads that jointly owned the only terminal in St. Louis that could feasibly accommodate traffic from the west could not deny their competitors access to the terminal on reasonable terms). See also Arizona $v$. Maricopa County Medical Society, 457 U.S. 332 (1982) (A "foundation" created by competing physicians to secure higher reimbursement was not a legitimate joint venture because there was no pooling of operations or sharing of risk among the participants. The physicians' agreements on price were per se illegal).

See text accompanying note 44 . 
described as benchmarking must still be defended under the rule of reason, which means establishing that it has beneficial effects for competition. ${ }^{60}$ The parties to benchmarking projects need to avoid per se conduct. It is critical that if benchmarking takes place among competitors, the parties articulate a pro-competitive reason for what and why they are benchmarking before they start. Benchmarking should not devolve to simply sharing information about output, prices and costs among competitors. If it does, then it may look like just plain old conspiracy.

The International Benchmarking Clearinghouse has established benchmarking "Rules of Conduct," the first principle of which is to "keep it legal." It is also a good resource for information about benchmarking.

\section{APPLICATION TO FOREIGN CONDUCT}

In 1982, the United States Congress enacted the Foreign Trade Antitrust Improvements Act. ${ }^{61}$ The FTAIA amended the Sherman Act to provide that it:

[s]hall not apply to conduct involving trade or commerce (other than import trade or import commerce) with foreign nations unless -

(1) such conduct has a direct, substantial, and reasonably foreseeable effect -

(A) on trade or commerce which is not trade or commerce with foreign nations, or on import trade or import commerce with foreign nations; or

(B) on export trade or export commerce with foreign nations, of a person engaged in such trade or commerce in the United States; and

(2) such effect gives rise to a claim under the provisions of [the Sherman Act], other than this section. .2 $^{2}$

The U.S. District Court in Chicago recently considered whether pleadings were sufficient to survive a motion to dismiss under the FTAIA in United Phosphorus, Ltd. v. Angus Chemical $\mathrm{Co}^{63}$ Two Indian companies and an Illinois company claimed the defendants, a Delaware company, its German subsidiary and its Indian customer, took anticompetitive acts to prevent the plaintiffs from entering the world market for certain chemicals that were essential precursors for manufacturing the drug of choice for treating tuberculosis in India. The defendants allegedly did this by filing an unsuccessful lawsuit against the plaintiffs in Illinois, interfering with efforts to manufacture the chemicals in the United States and India, refusing to sell the plaintiffs a necessary ingredient which only the defendants manufactured, and by interfering with

See B. Henry, "Benchmarking and Antitrust" (1994) 62 Antitrust Law Journal 483, for a thorough review of the applicable U.S. case law.

15 U.S.C. (1988) [hereinafter FTAIA].

Jbid., $\S 6(1)$ a.

No. 94C 2078, 1994 U.S. Dist. LEXIS 14786 (N.D. Ill. 1994). 
efforts to contract for the needed technology or to obtain customers. The Court concluded that allegations that this conduct prevented the plaintiffs from manufacturing product for sale in the United States met the FTAIA requirements of "direct, substantial and reasonably foreseeable effect" on United States commerce. However, the judge was not enthusiastic about the case:

[T]his court recognizes that Plaintiffs have sufficiently pled their claims to avoid a motion to dismiss. Recognizing the duty to allow these claims to proceed to a later stage of the litigation, however, does not necessarily require us to remain silent as to the possible insufficiency of those claims. This Complaint has managed to squeeze into the federal courthouse door on allegations of domestic antitrust injury. As the case proceeds, however, the parties are put on notice that the allegations will need to be much more than merely economic theories to survive later dispositive motions. ${ }^{\text {if }}$

On April 5, 1995, the DOJ and FTC issued joint Antitrust Enforcement Guidelines for International Operations. ${ }^{65}$ The Guidelines provide a summary of various antitrust laws likely to apply to international transactions and state the agencies' approach to the applicability of U.S. antitrust law to hypothetical situations.

The topics covered include the Agencies' subject matter jurisdiction over conduct and entities outside the United States and the considerations, issues, policies, and processes that govern their decision to exercise that jurisdiction; comity; mutual assistance in international antitrust enforcement; and the effects of foreign government involvement on the antitrust liability of private entities.... Finally, to illustrate how these principles may operate in certain contexts, the Guidelines include a number of examples. $^{66}$

The Guidelines are deliberately aggressive, intending to assert the full scope of U.S. jurisdiction over anticompetitive activities that have a reasonably foreseeable impact on U.S. commerce. The Guidelines include illustrative examples demonstrating how the agencies view their applicability. The most relevant one is also the least controversial: cartels raising the price or restricting the output of products imported into the United States are clearly subject to attack under the U.S. antitrust laws, provided all other conditions for jurisdiction are met. This is consistent with the position taken by the European Economic Community in the Woodpulp ${ }^{67}$ case, and should not create a lot of controversy. It does, however, have an enormous impact on an industry that sells most of its output across the border, particularly when many of the customers are utilities regulated by state public utility commissions. Stanislaus v. Pacific Gas \& Electric illustrates the risk. Future plaintiffs may not be satisfied to list the Canadian suppliers as unnamed co-conspirators.

Of particular interest is the way the agencies approach jurisdiction over foreign mergers and acquisitions. In Illustrative Example $\mathrm{H}$, the Guidelines posit a Canadian

4 Trade Reg. Rep. (CCH) I 20,589-2 (4 November 1995) [hereinafter Guidelines].

Ibid. at 1.

67 Woodpulp, sub nom. Ahlstrom Osakyhitio v. Commission (1988), 4 Common Mkt. Rep. CCH I 14,491 
and a French firm importing a substantial amount into the United States. Both firms have sales offices in the United States and are subject to personal jurisdiction in the U.S., although neither produces product in the U.S. The Guidelines state that the agencies could assert jurisdiction over a proposed merger between the two foreign firms based on its impact on U.S. imports.

If the facts ... were modified to show that the proposed merger would have effects on U.S. export commerce, as opposed to import trade, then in assessing jurisdiction ... the Agencies would analyze the question of effects on commerce in a manner consistent with the FTAlA: that is, they would look to see whether the effects on U.S. domestic or import commerce are direct, substantial and reasonably foreseeable....

In both these situations, the Agencies would conclude that ... jurisdiction technically exists. However, if effective relief is difficult to obtain, the case may be one in which the Agencies would seek to coordinate their efforts with other authorities who are examining the transaction. ${ }^{68}$

In s. 4.2 , regarding investigatory practice relating to foreign nations, the Guidelines slide over the source of the greatest dismay from foreign companies. A great deal of the dismay arises because in private antitrust litigation U.S. courts issue discovery orders against foreign companies. Those orders can be incredibly burdensome and intrusive and often display insufficient concern for the legitimate privacy or commercial secrecy concerns of the companies subjected to the orders. The companies become particularly upset when they have been brought into such private antitrust litigation as defendants. The Guidelines do not cover the risk of private litigation by competitors, consumers and suppliers under state and federal antitrust laws, nor do they cover the risk of state prosecutions.

\section{NOERR-PENNINGTON DOCTRINE}

Eastern Railroad Presidents Conference v. Noerr Motor Freight, Inc. ${ }^{69}$ and United Mine Workers of America v. Pennington ${ }^{70}$ are the two cases that gave the NoerrPennington doctrine its name. Companies petitioning the government have antitrust immunity for that activity. This immunity includes companies' activities before regulatory agencies and information gathering activities by trade associations ancillary to lobbying or similar activities. This is a powerful exception to the pervasive presence of antitrust and it protects many trade association activities. The immunity applies even though the association seeks regulatory or other relief that would do serious injury to other segments of a regulated industry and despite the fact that many commentators perceive that some of the most anticompetitive outcomes occur because they are mandated by the government. This is particularly true of industries that are heavily regulated as to output and price, as was the case when the oil industry in the United States was subject to pervasive regulation by the Department of Energy. It continues

$70 \quad 381$ U.S. 657 (1965) 
to be true of regulated industries, such as network industries of which pipelines are a good example, where different segments jockey for position in the regulatory arena.

McGuire Oil Company v. Mapco, Inc. ${ }^{71}$ dramatically illustrates the power of the Noerr-Pennington immunity. The trade association for independent branded jobbers engaged in the wholesale and retail sale of branded gasoline had successfully lobbied the Alabama state legislature to pass a statute prohibiting the retail sale of motor fuel below cost. ${ }^{72}$ Mapco had been following a pricing strategy at its retail stations of pricing one to two cents below major branded competitors. Soon after the below cost statute passed, the members of the jobber trade association began monitoring the sales of gasoline in Alabama to find violators. Mapco became a target of the jobbers efforts, and they told Mapco they would sue it under the state statute unless Mapco raised its prices at its retail stations. When Mapco did not comply to their satisfaction, the jobbers sued under the state below-cost statute. Mapco counterclaimed under the antitrust laws. The Court put it very succinctly:

\begin{abstract}
...Mapco claims that the [jobbers] engaged in a concerted effort to establish minimum prices for gasoline in the Mobile area, and that this effort manifested itself in threats and coercion of those independent retailers, like Mapco, who sought to preserve their market share by pricing gas one or two cents below major brand gas prices....
\end{abstract}

Mapco's claims under the Sherman Act are barred by the immunity granted [jobbers] under the NoerrPennington doctrine."

This is very aggressive use of the Noerr-Pennington immunity. It probably would not be wise for big oil companies to attempt it.

One of the most dangerous antitrust periods for industries is when the entire industry is moving from a regulated environment in which they were permitted to discuss price and output freely under the Noerr-Pennington immunity to an environment in which they are expected to compete like everyone else and conversations that were immune yesterday become actionable today. That is where the Canadian oil and gas industry is today: in the throes of deregulation with the holdover mindset that companies can and should discuss everything with other oil and gas companies. The danger period lasts as long as the participants in the industry continue to have the regulated mindset and it requires continued antitrust education during the transition period. We have been going through that process in the United States for a number of years. The need for continued education never ends.

The Noerr-Pennington doctrine interacts with notions of jurisdiction, comity and defences based on foreign sovereign compulsion when parties are obeying orders of

State below-cost sales statutes are increasingly common. Cost is a very illustrative concept for refiners. The state statutes often contain presumptions about calculating costs that make pricing in response to the market very difficult.

Supra note 71 at 1557. 
foreign authorities. It is reasonably clear there is jurisdiction if the Canadian companies are exporting their production into the United States, and a U.S. court would have no qualms about permitting discovery into Canadian meetings and activities if it appeared that the companies were fixing the price for production exported from Canada. The Guidelines make the following remarks about jurisdiction: "the Sherman Act applies to foreign conduct that was meant to produce and did in fact produce some substantial effect in the United States... Imports into the United States by definition affect the U.S. market directly, and will, therefore, almost invariably satisfy the intent part of the Hartford Fire test. ${ }^{174}$

Under the Guidelines, international comity is one of the issues the agencies will consider:

[I]n determining whether to assert jurisdiction to investigate or bring an action, or to seek particular remedies in a given case, each Agency takes into account whether significant interests of any foreign government would be affected.

In performing a comity analysis, the Agencies take into account all relevant factors. Among others, these may include (1) the relative significance to the alleged violation of conduct within the United States, as compared to conduct abroad; (2) the nationality of the persons involved in or affected by the conduct; (3) the presence or absence of a purpose to affect U.S. consumers, markets, or exporters; (4) the relative significance and foreseeability of the effects of the conduct on the United States as compared to the effects abroad; (5) the existence of reasonable expectations that would be furthered or defeated by the action; (6) the degree of conflict with foreign law or articulated foreign economic policies; (7) the extent to which the enforcement activities of another country with respect to the same persons, including remedies resulting from those activities, may be affected; and (8) the effectiveness of foreign enforcement as compared to U.S. enforcement action. ${ }^{\text {"s }}$

From the agencies' perspective, once they have considered the comity issues, the matter is closed. "The [United States Department of Justice] does not believe that it is the role of the courts to 'second-guess the executive branch's judgment as to the proper role of comity concerns under these circumstances.' ${ }^{\prime 76}$ In litigation brought by private plaintiffs, it may not be wise to bet one's defence on a U.S. judge dismissing an aggressive plaintiff's lawsuit against Canadian companies on grounds of comity. ${ }^{77}$

The Guidelines establish certain criteria under which the agencies will forego enforcement on the ground of foreign sovereign compulsion. First, the foreign government must have compelled the anticompetitive conduct under circumstances in

Supra note 65 at 20,589-9, citing Hartford Fire Insurance Co. v. California, 113 S.Ct. 2891 at 2909 (1993).

Ibid. at 20,589-12.

lbid. at 20,589-13.

While in the antitrust case filed by the County of Stanislaus the Court dismissed most of the case, that was by no means a foregone conclusion and it did so because the rates were regulated by U.S. agencies, invoking the filed rate doctrine. See text accompanying supra note 30. 
which failure to comply will result in severe sanctions. ${ }^{78}$ Secondly, "the defence normally applies only when the foreign government compels conduct which can be accomplished entirely in its own territory. [If the compelled conduct occurs in the United States, the Agencies will not permit the defence.] ... [Thirdly, it does not apply when the foreign government is acting in its commercial capacity]." 79

However, the Guidelines state:

Under the Noerr-Pennington doctrine, a genuine effort to obtain or influence action by governmental entities in the United States is immune from application of the Sherman Act, even if the intent or effect of that effort is to restrain or monopolize trade .... [T] he Agencies will apply it in the same manner to the petitioning of foreign governments and the U.S. Government. ${ }^{\text {so }}$

\section{PRE-MERGER NOTIFICATION}

Under the Hart-Scott-Rodino Act, ${ }^{81}$ certain mergers, acquisitions, and joint ventures must be notified to the FTC and the DOJ before the parties can consummate their transaction. This includes transactions involving foreign firms that sell products into the United States if the transaction otherwise meets the HSR requirements. The filing rules are too complicated to review in any detail in this article. In general, both parties to the transaction must file if: (1) one person has sales or assets of at least U.S. $\$ 100$ million; (2) the other person has sales or assets of at least U.S. $\$ 10$ million; and (3) as a result of the transaction, the acquiring person will hold a total amount of stock or assets of the acquired person valued at more than U.S. $\$ 15$ million. The formation of a joint venture may be subject to notification under the HSR if the parties transfer assets to the joint venture or buy stock in the joint venture. Asset transfers include credit guarantees for the joint venture.

Filing has become expensive. The filing fee must be paid by the buyer and the agencies have recently increased it to U.S. $\$ 45,000 .{ }^{82}$ The possible need to file a premerger notification and wait at least thirty days before the parties can close the transaction must be taken into account in planning any transaction.

This is distinguished from the defence based on the "state action doctrine," which arises from constitutional principles of federalism and applies to actions of a state of the United States. The state action doctrine applies to private anticompetitive conduct that is both undertaken pursuant to clearly articulated state policies and is actively supervised by the state; it does not require compulsory orders of states or their political subdivisions. Supra note 65 at 20,589-15.

so Ibid. at 20,589-16.

s) Hart-Scott-Rodino Act, 15 U.S.C.S. $\$ \$ 1311 \mathrm{ff}$ (1976) [hereinafter HSR].

82 The penalties for failing to file can be pretty hefty and embarrassing. For example, Pennzoil was assessed a civil penalty of $\$ 2.6$ million for failing to file a premerger notification until ten months after buying approximately 9 percent of Chevron's voting stock. The DOJ claimed that the "investment only exemption" did not apply because Pennzoil's purchase of Chevron's stock was not solely for the purpose of investment at the time it bought. See U.S. v. Pennzoil Co., 6 Trade Reg. Rep. (CCH) I 45,094 (Case 4096) (27 September 1994). 
Participants in antitrust legal education programs in the United States spend a lot of time complaining about pre-merger notifications and the way the agencies bully parties to a deal into entering into onerous consent decrees, but this occurs only in a small fraction of the total filings. In the United States, the oil and gas business is so unconcentrated that almost all transactions to buy, sell or merge in the upstream part of the oil and gas business go through with "early termination." ${ }^{183}$ Transactions in downstream parts of the business, such as pipeline transportation, often attract more attention. Buying a refinery can create major headaches for both buyer and seller, attracting opposition from jobbers and other customers, who may sue or invite intervention in the acquisition by one or more state attorneys general.

In approaching an acquisition that may be subject to review by the U.S. agencies, the most important thing is for the antitrust lawyers to be brought into the acquisition early enough that they can review the deal with an eye to agency approval. Getting an economist involved early is a good idea if the parties expect any difficulty with the review. Economists play an important role in the review process at both the FTC and the DOJ. The parties may have a better chance of convincing the agency economists that the acquisition will not harm competition than of convincing the agency lawyers.

The main thing to watch out for are documents prepared by or for the clients that describe the acquisition in "power" language or that purport to describe the relevant markets. Documents prepared to obtain management approval of the acquisition must be submitted with the HSR filing. The worst offenders are investment bankers and consultants, or business people who have been infected with "consultant speak." It is extremely important that these documents not be loaded with narrow market definitions or. language implying the acquisition will increase the buyer's market power.

If the agency does not approve the deal within the thirty-day waiting period, then the agency will issue a second request for more information and prevent closing until after the parties to the deal are in "substantial compliance" with the second request. Second requests are extremely burdensome and expensive, despite repeated agency statements that they have tried to streamline and narrow the scope of the second request process. If the parties anticipate that the acquisition will present any difficulties at all, they should try to avoid the second request process by answering all of the agency's questions before the end of the thirty-day waiting period. The parties should also make it clear that they will respond to any information requests the agencies make; find out who within the agency staff will be handling the matter; and work with the staff to make sure they get the information that they need to do their job early in the process.

The DOJ and the FTC issued updated Horizontal Merger Guidelines in 1992 to explain how they analyze markets in conducting merger reviews. The merger guidelines are beyond the scope of this article. Most oil and gas transactions, regardless of dollar amount, fall well below the market threshold of either agencies' concern. See 57 Fed. Reg. No. 176, 41,552 (1992). The FTC recognized this by amending the filing rules effective April 29, 1996 to exempt acquisitions of carbon-based mineral reserves so long as the value of the reserves does not exceed U.S. $\$ 500$ million. See 61 Fed. Reg. No. 61, 13,666-89 (28 March 1996). 
The introduction commented that a dual system of antitrust economic analysis seems to have developed. The enforcement agencies seem to have adopted more interventionist philosophies than prevailed earlier and they can impose these philosophies in the merger and acquisition field with very little judicial intervention. Companies simply cannot litigate against the government while a deal is on hold and will often agree to onerous consent orders to be able to close the transaction. When the government does end up in court on its more aggressive stances, it often loses.

\section{CONCLUSION}

This article was intended to provide a brief overview of aspects of United States antitrust law that may impact Canadian oil and gas producers. Clients should be advised to avoid per se conduct which carries severe criminal penalties and to note that the U.S. authorities will seek the cooperation of Canadian enforcement authorities to pursue such violations. U.S. civil litigation brought by private parties presents another potential hazard for companies exporting to the United States market. Clients should avoid information exchanges with competitors about prices, output or other competitively significant issues to avoid the appearance of per se agreement.

The FTC and the DOJ will extend Noerr-Pennington antitrust immunity to the activities of companies petitioning the Canadian or provincial governments or regulatory authorities about matters affecting the oil and gas markets. However, anticompetitive activities cannot be defended under the doctrine of foreign sovereign compulsion unless they are compelled by the government.

In any acquisition, merger or joint venture, the parties should keep in mind that they may need to file a $H S R$ notification with U.S. authorities in addition to review under Canadian law, even if both companies are non-U.S. companies, if they import into the United States. Finally, pre-merger notification procedures need to be part of the acquisition or joint venture time table. 